\title{
Penyuluhan Wirausaha untuk Meningkatkan Ekonomi Keluarga dengan Daur Ulang Barang Bekas Desa Mekarsari Kabupaten Bogor
}

\author{
Irmal $^{1 *}$, Theobaldus Boro Tura ${ }^{2}$, Pranoto $^{3}$, Jasmani $^{4}$, Endang Surgiarti ${ }^{5}$ \\ 1,2,3,4,5 Program Studi Manajemen, Fakultas Ekonomi, Universitas Pamulang \\ Jl. Surya Kencana No.1, Pamulang Barat, Kec. Pamulang \\ Kota Tangerang Selatan, Banten 15417 \\ *Penulis Korespodensi: dosen01047@unpam.ac.id
}

\begin{abstract}
ABSTRAK
Penyuluhan wirausaha home industry untuk meningkatkan ekonomi keluarga dengan daur ulang barang bekas, hadir untuk memberikan pengetahuan, wawasan dan peluang yang sangat potensial dikembangkan, karena bahan bakunya murah dan mudah diperoleh. Tujuan dari penyuluhan wirausaha home industry untuk meningkatkan ekonomi keluarga dengan daur ulang barang bekas agar masyarakat setempat dapat meningkatkan ekonomi keluarga dengan berkreasi, berkarya dan berdaya juang untuk mengubah barang bekas yang tidak bernilai secara ekonomis menjadi barang yang bernilai guna serta bernilai ekonomi tinggi.
\end{abstract}

Kata Kunci : Wirausaha

\begin{abstract}
Counseling home industry entrepreneurs to improve the family economy by recycling used goods, is here to provide knowledge, insight and opportunities that are very potential to be developed, because raw materials are cheap and easy to obtain. The purpose of counseling home industry entrepreneurs is to improve the family economy by recycling used goods so that the local community can improve the family economy by creating, working and struggling to convert used goods that are not economically valuable into goods of high value and economic value.
\end{abstract}

Keywords: Entrepreneurship

\section{PENDAHULUAN}

Kegiatan pengabdian masyarakat merupakan salah satu Tri Dharma Perguruan Tinggi Selain Pendidikan dan Penelitian, sesuai undang-Undang RI Nomor 20 Tahun 2003 tentang Sistem Pendidikan Nasional, pada Pasal 20 ayat 2 dinyatakan: "Perguruan Tinggi berkewajiban menyelenggarakan pendidikan, penelitian dan pengabdian masyarakat". Pada Pasal 24 ayat 2 disebutka "Perguruan tinggi memiliki otonomi untuk mengelola sendiri lembaganya sebagai pusat penyelenggaraan pendidikan tinggi, penelitian ilmiah, dan pengabdian masyarakat".

Pengabdian kepada masyarakat merupakan pelaksanaan pengamalan ilmu pengetahuan, teknologi dan seni budaya langsung pada masyarakat secara kelembagaan melalui metodologi ilmiah sebagai penyebaran Tri Dharma Perguruan Tinggi serta 90 
tanggung jawab yang luhur dalam usaha mengembangkan kemampuan masyarakat, sehingga dapat mempercepat laju pertumbuhan tercapainya tujuan pembangunan nasional.

Program pengabdian kepada masyarakat merupakan salah satu program yang wajib dilaksanakan, baik oleh dosen maupun oleh mahasiswa, dengan berlandaskan pada prinsip-prinsip: motivasi pemenuhan kompetensi akademik, jiwa kewirausahaan (entrepreneurship), dan profesional serta kesehatan masyarakat khususnya anak-anak calon penerus bangsa, sehingga dapat menghasilkan program pengabdian kepada masyarakat yang bermutu, relevan, dan sinergis dalam meningkatkan pemberdayaan masyarakat.

Manajemen merupakan salah satu program studi di Universitas Pamulang. Program studi ini memiliki andil dalam mencetak lulusan yang berkarakter serta mampu bersaing di dalam dunia kerja, serta dapat berperan bagi pembangunan. Pengabdian kepada masyarakat adalah bentuk Kegiatan pengabdian masyarakat merupakan salah satu Tri Dharma Perguruan Tinggi Selain Pendidikan dan Penelitian, sesuai undang-Undang RI Nomor 20 Tahun 2003 tentang Sistem Pendidikan Nasional, pada Pasal 20 ayat 2 dinyatakan: "Perguruan Tinggi berkewajiban menyelenggarakan pendidikan, penelitian dan pengabdian masyarakat". Pada Pasal 24 ayat 2 disebutkan:'Perguruan tinggi memiliki otonomi untuk mengelola sendiri lembaganya sebagai pusat penyelenggaraan pendidikan tinggi, penelitian ilmiah, dan pengabdian masyarakat".

Pengabdian kepada masyarakat merupakan pelaksanaan pengamalan ilmu pengetahuan, teknologi dan seni budaya langsung pada masyarakat secara kelembagaan melalui metodologi ilmiah sebagai penyebaran Tri Dharma Perguruan Tinggi serta tanggung jawab yang luhur dalam usaha mengembangkan kemampuan masyarakat, sehingga dapat mempercepat laju pertumbuhan tercapainya tujuan pembangunan nasional.

Program pengabdian kepada masyarakat merupakan salah satu program yang wajib dilaksanakan, baik oleh dosen maupun oleh mahasiswa, dengan berlandaskan pada prinsip-prinsip: motivasi pemenuhan kompetensi akademik, jiwa kewirausahaan (entrepreneurship), dan profesional, sehingga dapat menghasilkan program pengabdian kepada masyarakat yang bermutu, relevan, dan sinergis dalam meningkatkan pemberdayaan masyarakat.

Manajemen merupakan salah satu program studi di Universitas Pamulang. Program studi ini memiliki andil dalam mencetak lulusan yang berkarakter serta mampu bersaing di dalam dunia kerja, serta dapat berperan bagi pembangunan. Pengabdian kepada masyarakat adalah bentuk Kegiatan pengabdian masyarakat merupakan salah satu Tri Dharma Perguruan Tinggi Selain Pendidikan dan Penelitian, sesuai undang-Undang RI Nomor 20 Tahun 2003 tentang Sistem Pendidikan Nasional, pada Pasal 20 ayat 2 dinyatakan: "Perguruan Tinggi berkewajiban menyelenggarakan pendidikan, penelitian dan pengabdian masyarakat". Pada Pasal 24 ayat 2 disebutkan:"Perguruan tinggi memiliki otonomi untuk mengelola sendiri lembaganya sebagai pusat penyelenggaraan pendidikan tinggi, penelitian ilmiah, dan pengabdian masyarakat".

Pengabdian kepada masyarakat merupakan pelaksanaan pengamalan ilmu pengetahuan, teknologi dan seni budaya langsung pada masyarakat secara kelembagaan 
Irmal, dkk

melalui metodologi ilmiah sebagai penyebaran Tri Dharma Perguruan Tinggi serta tanggung jawab yang luhur dalam usaha mengembangkan kemampuan masyarakat, sehingga dapat mempercepat laju pertumbuhan tercapainya tujuan pembangunan nasional.

Kantong plastik yang sudah dibeli ternyata pada akhirnya tetap dibuang dan menjadi sampah. Bermula dari inisiatif para pecinta lingkungan mencoba melihat ini sebagai permasalahan sekaligus peluang. Mereka berinisiatif untuk mendaurulang sampah kantong plastik itu jadi sesuatu yang berguna. Taman Belajar Kreatif Mekarsari yang berisi anak-anak muda dapat mengembangkannya menjadi salah satu kegiatan belajar kreatif sekaligus berupaya untuk tidak menjadi salah satu penyumbang sampah yang sangat mengganggu lingkungan serta menciptakan solusi untuk permasalahan sampah di lingkungan. Pelatihan daur ulang tersebut berawal dari keresahan yang melihat banyak sampah plastik bekas bungkus kopi dan minuman instan lainnya yang hanya dibuang begitu saja.

Dari kondisi tersebut, mereka melihat adanya peluang untuk memanfaatkannya menjadi sesuatu yang bermanfaat. Pelaksanaan kegiatan dimulai dengan penyampaian materi secara langsung di depan peserta pelatihan. Kemudian dilanjutkan dengan praktik daur ulang sampah plastik menjadi berbagai macam kerajinan tangan dengan pendampingan tim ahli. kegiatan tersebut bertujuan untuk membantu mengurangi keberadaan sampah plastik di lingkungan. Selain itu juga dapat digunakan untuk meningkatkan ekonomi dan kreativitas masyarakat setempat. Diharapkan dengan adanya program ini, Taman Belajar Kreatif Mekarsari dan juga masyarakat di sini bisa melihat dan mengambil peluang dengan memanfaatkan bungkus plastik bekas kopi menjadi tas dan dompet atau perlengkapan rumah tangga. Sehingga nantinya akan mampu untuk membantu meningkatkan perekonomian mereka.

\section{METODE PELAKSANAAN}

Metode pelaksanaan menggunakan teknik penyuluhan dengan menggunakan proyektor, seminar, diskusi forum dan tanya jawab, kegiatan dilaksanakan pada hari Kamis, tanggal 24 April 2020 sampai dengan Sabtu, 26 April 2020

Metode pelaksanaan program pengabdian kepada masyarakat sebagai berikut:

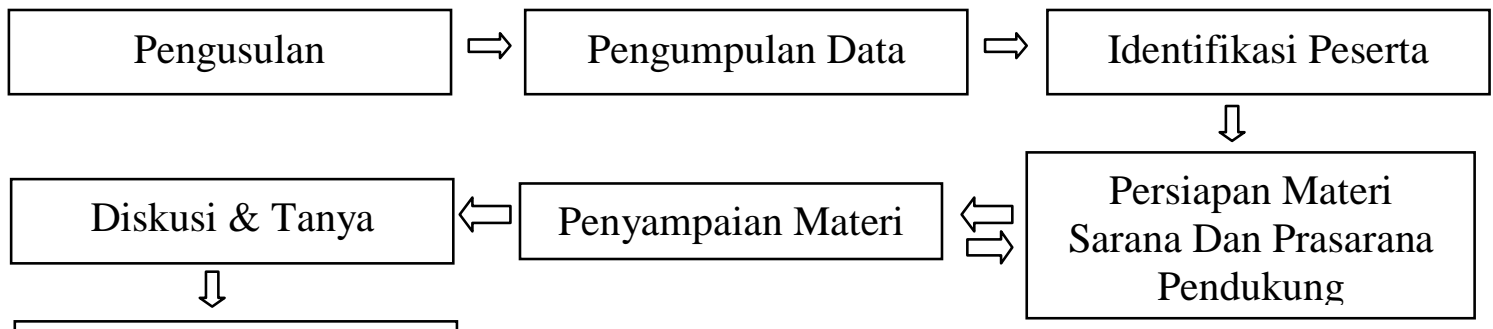

Monitoring \& Evaluasi

Pelaporan \& Publikasi

\section{Alur Kegiatan Pengabdian \\ Kepada Masyarakat}




\section{HASIL DAN PEMBAHASAN}

Dengan menggunakan diskusi kelompok, penyuluhan ini mengedukasi pengelola Taman Belajar Kreatif Mekarsari akan pemanfaatan limbah plastic (bungkus kopi instan) Akhir-akhir ini berita mengenai limbah plastik semakin mengkhawatirkan. Pasalnya limbah plastik ini bukan hanya ada di daratan saja, melainkan di lautan. Namun tak semua yang berbahan plastik harus berakhir menjadi limbah. Pasalnya ada pula yang menggunakan plastik sebagai bahan kerajinan dan juga meningkatkan kreativitas. Salah satu yang sering digunakan ialah bungkus kopi. Bungkus kopi sendiri cukup sering dikreasikan menjadi berbagai hal seperti dompet maupun tas, terutama oleh para ibu-ibu pelaku UKM.

Cara membuat tas dari bungkus kopi ini termasuk ramah lingkungan. Karena bisa membantu untuk mengurangi sampah plastik. Selain itu, tentu saja hasil dari kerajinan ini bisa kamu gunakan dan juga ramah lingkungan. Untuk cara membuat tas dari bungkus kopi ini pun membutuhkan tingkat kreativitas serta keahlian. Tapi bila kamu belum bisa dan mengetahui cara membuat tas dari bungkus kopi, kamu bisa berlatih secara mandiri ataupun dengan bantuan orang lain. Karena sampah plastik sendiri termasuk dalam jenis sampah yang susah terurai, maka mendaur ulang dengan cara membuat tas dari bungkus plastik ini patut untuk kamu coba. Bahkan tas daur ulang ini bisa digunakan untuk menaruh barang saat berbelanja

\section{PENUTUP}

Pelaksanaan kegiatan pengabdian masyarakat oleh lembaga penelitian dan pengembangan masyarakat (LPPM) Universitas Pamulang. Acara kegiatan pengabdian kepada masyarakat ini dilaksanakan selama 3 hari, yaitu sebagai berikut.Pertama, pembukaan oleh Ketua Pengurus Taman Belajar Kreatif Mekar Sari kemudian dilanjutkan laporan dari Ketua Kegiatan sekaligus penjelasan pelatihan dan pembagian bahan praktek dan contoh model produk .Selanjutnya yaitu pemberian motivasi berwirausaha oleh narasumber. Kedua, kegiatan demonstrasi pembuatan produk usaha berbahan dasar sampah plastik. Ketiga yaitu kegiatan penyuluhan mengenai bagaimana hasil produk tersebut dibuat sebagai kegiatan wirausaha

\section{DAFTAR PUSTAKA}

Aviliani, R dan Wilfridus, L. 1997. Membangun Kepuasan Pelanggan Melalui Kualitas Pelayanan. Usahawan, No.5

D Sunarsi. (2020). Kepemimpinan Bisnis Strategik. Kota Serang: Desanta Muliavisitama

Djarwanto. 1996. Mengenal beberapa Uji Statistik dalam Penelitian.Yogyakarta: Liberti.Djarwanto, PS dan Subagyo,

Freddy Rangkuti. 2002. Measuring Customer Satisfaction(cetakan ketiga).Jakarta: PT.Gramedia Pustaka Utama.

Ghozali, Imam. 2000. Aplikasi Analisis Multivariate dengan SPSS. Semarang: Universitas Diponegoro. 
Irmal, dkk

Ghozali, Imam. 2005. Aplikasi Analisis Multivariate dengan SPSS. Semarang: Universitas Diponegoro.

Ghozali, Imam. 2006.Aplikasi Analisis Multivariate denganSPSS. Semarang: Universitas Diponegoro

Gumilar, I., Sunarsi, D. (2020). Comparison of financial performance in banking with high car and low car (Study of banks approved in the kompas 100 index for the period 2013-2017). International Journal of Psychosocial Rehabilitation. Volume 24 - Issue 7

Maddinsyah, A., Sunarsi, D., Hermawati, R., Pranoto. (2020). Analysis of location selection effect on the user decision that influcence the success of the service business of micro, small and medium enterprise (MSME) in bandung timur region. International Journal of Advanced Science and Technology. Vol. 29 No. 06

Pangestu.1998. Statistik Induktif. Edisi IV. Yogyakarta: BPFE.Engel, et al. 2000. Perilaku Konsumen. Terj.F.X. Budianto. Jakarta : Binarupa Aksara.

Sunarsi, D. (2018). Buku Ajar: Seminar Perencanaan Sumber Daya Manusia. Tangerang Selatan: Asmoro Mediatama

Sunarsi, D., \& Kusjono, G. (2019). Pengaruh Lingkungan Kerja Non Fisik, Konflik Dan Turn Over Intention Terhadap Produktivitas Kerja Karyawan Pada CV. Usaha Mandiri Jakarta Selatan. Jurnal Ekonomi Efektif, 1(3).

Sunarsi, D., Kustini, E., Lutfi, A. M., Fauzi, R. D., \& Noryani, N. (2019). Penyuluhan Wirausaha Home Industry Untuk Meningkatkan Ekonomi Keluarga Dengan Daur Ulang Barang Bekas. BAKTIMAS: Jurnal Pengabdian pada Masyarakat, 1(4), 188-193. 